\title{
A BILATERALLY CRYPTORCHID SPRINGBOK RAM, ANTIDORCAS MARSUPIALIS MARSUPIALIS
}

\author{
J. D. SKINNER \\ Research Institute for Animal and Dairy Science, \\ Division of Animal Physiology, Irene, South Africa
}

(Received 23rd November 1970, revised 11th March 1971)

Reports of abnormal reproductive development in feral antelope are rare. Skinner \& Huntley (1971) have given details of an intersex kudu but there have been no reports of such abnormalities in gazelle. During recent studies on the reproduction of the springbok (Skinner \& van Zyl, 1970, 1971) 250 rams were shot. Of these, one was found to be bilaterally cryptorchid and is the subject of this communication.

Apart from the fact that no scrotum or pouch formation was present, the ram was phenotypically identical to normal rams. It weighed $36.4 \mathrm{~kg}$ compared with $36.7 \pm 1 \cdot 1 \mathrm{~kg}$ for six normal rams shot at the same time. The pituitary gland weighed only $0.2 \mathrm{~g}$ compared with $0.5 \pm 0.1 \mathrm{~g}$ for normal rams. After cutting through the pubic symphysis, the reproductive tract was removed and dissected. Cranial to the bulbourethral glands, the tract was abnormal and is illustrated in Pl. 1, Fig. 1. The bulbourethral glands weighed $2 \cdot 1 \mathrm{~g}$ (cf. $3.0 \pm 0.3 \mathrm{~g}$ for the six normal rams) and there were paired, apparently normal, seminal vesicles weighing $4.6 \mathrm{~g}$ (cf. $9.6 \pm 1.2 \mathrm{~g}$ ) and containing $328 \mathrm{mg}$ fructose $/ 100 \mathrm{~g}$ and $60 \mathrm{mg}$ citric acid/100 g (cf. $484 \pm 26 \mathrm{mg}$ fructose and $99 \pm 13 \mathrm{mg}$ citric acid/100 g, respectively, for six normal rams as determined by the method of Lindner \& Mann, 1960). The ampullae were fused for most of their length with the uterus masculinus (Pl. 1, Fig. 1, u) which continued cranially and divided into two Müllerian ducts which fused blindly with the epididymides, the whole weighing $57 \cdot 1 \mathrm{~g}$.

The pars glandularis or ampulla (Pl. 1, Fig. 1, a) was linked to the ductus epididymidis on each side by a ductus deferens. The fused ampullae and uterus masculinus consisted of three tubes which were not completely separate for their entire length, having a common lumen in the middle portion. This contained $1.5 \mathrm{ml}$ of fluid which, when analysed, was found to contain $880 \mathrm{mg}$ fructose $/ 100 \mathrm{ml}$ and $138 \mathrm{mg}$ citric acid/100 ml. A small amount of fluid from the uterus of a normal ewe was found to contain $7 \mathrm{mg}$ fructose $/ 100 \mathrm{ml}$.

Pieces of both gonads and of other parts of the tract were fixed in Bouin's fluid and, after routine embedding in paraffin wax, they were sectioned at 6 $\mu \mathrm{m}$. Pieces of testis were also fixed in Zenker-formol and postchromed in potassium dichromate according to Threadgold's Method 1 (1957) for later staining with Sudan black for interstitial cells. The tissue fixed in Bouin's fluid was stained with Delafield's haematoxylin and chromotrope 2R.

The histology of the ductus epididymidis was similar to that in the normal 
ram but there were only three lumina, one of which was very large. Stereociliated columnar cells lined these lumina and resembled cells from normal epididymides. The ductus deferens also resembled that in the normal male, as did the ampullae.

The Müllerian ducts consisted of a single tube, the mucosa bearing simple columnar epithelium with endometrial glands. Where the uterus masculinus fused with the ampullae, the dorsal wall was the same as that in the Müllerian ducts but the ventral wall had a vesicular structure. The structures of the seminal vesicles and bulbourethral glands were similar to those of the normal male.

The paired testes weighed $36.4 \mathrm{~g}$ (cf. $64 \cdot 7 \pm 6.5 \mathrm{~g}$ for normal males). The seminiferous tubules in both gonads were developed and lined with sustentacular cells (Pl. 1, Fig. 2). Leydig cells were present but rather sparse (Pl. 1, Fig. 3). The mean tubule diameter was $75.9 \mu \mathrm{m}$ compared with $209.9 \pm 3.3 \mu \mathrm{m}$ for the normal rams. In $15 \%$ of the tubules, resting or dividing spermatogonia or primary spermatocytes were observed ( $\mathrm{Pl}$. 1, Figs. 4, 5,6), but spermatogenesis did not progress beyond this stage.

This was a normal male in which neither testis had descended and the uterus masculinus had not regressed.

The only other abnormalities observed amongst the springbok shot were two instances where a third ampulla was present. This was not linked by a vas deferens to the testis. These ampullae were assayed for fructose and citric acid and found to contain $6 \mathrm{mg}$ fructose $/ 100 \mathrm{~g}$ and $18 \mathrm{mg}$ citric acid/100 g compared with $100 \mathrm{mg}$ fructose $/ 100 \mathrm{~g}$ and $32 \mathrm{mg}$ citric acid/100 $\mathrm{g}$ for the connected ampullae. They were slightly lighter $(1.2 \mathrm{~g}$ compared to $1.5 \mathrm{~g})$ but appeared histologically similar to normal ampullae. This observation supports the theory of Skinner \& Rowson (1968) that testosterone in the testicular fluid has a local effect on the ampullae.

I am grateful to Mr J. H. M. van Zyl and his staff of the Division of Nature Conservation, Pretoria, who were responsible for shooting the rams. Thanks are due to $\mathrm{Dr}$ W. H. Gerneke for his comments on the manuscript.

\section{REFERENCES}

LiNDNER, H. R. \& MANN, T. (1960) Relationship between the content of androgenic steroids in the testes and secretory activity of the seminal vesicles in the bull. F. Endocr. 21, 341 .

Skinner, J. D. \& HuntLey, B. J. (1971) The sexual cycle in the kudu bull, Tragelaphus strepsiceros Pallas. Zool. Afr. 6 (2).

Skinner, J. D. \& Rowson, L. E. A. (1968) Some effects of unilateral cryptorchism and vasectomy on sexual development of the pubescent ram and bull. 7. Endocr. 42, 311.

Skinner, J. D. \& van ZYL, J. H. M. (1970) The sexual cycle in the springbok ram, Antidorcas marsupialis marsupialis Zimmermann. Proc. S. Afr. Soc. Anim. Prod. 9, 197.

SxinNER, J. D. \& vAN ZXL, J. H. M. (1971) The post-natal development of the reproductive tract of the springbok ram lamb, Antidorcas marsupialis marsupialis Zimmermann. Zool. Afr. 6 (2).

Threadgold, L. T. (1957) Sudan black and osmic acid as staining agents for testicular interstitial cells. Stain Technol. 32, 267. 

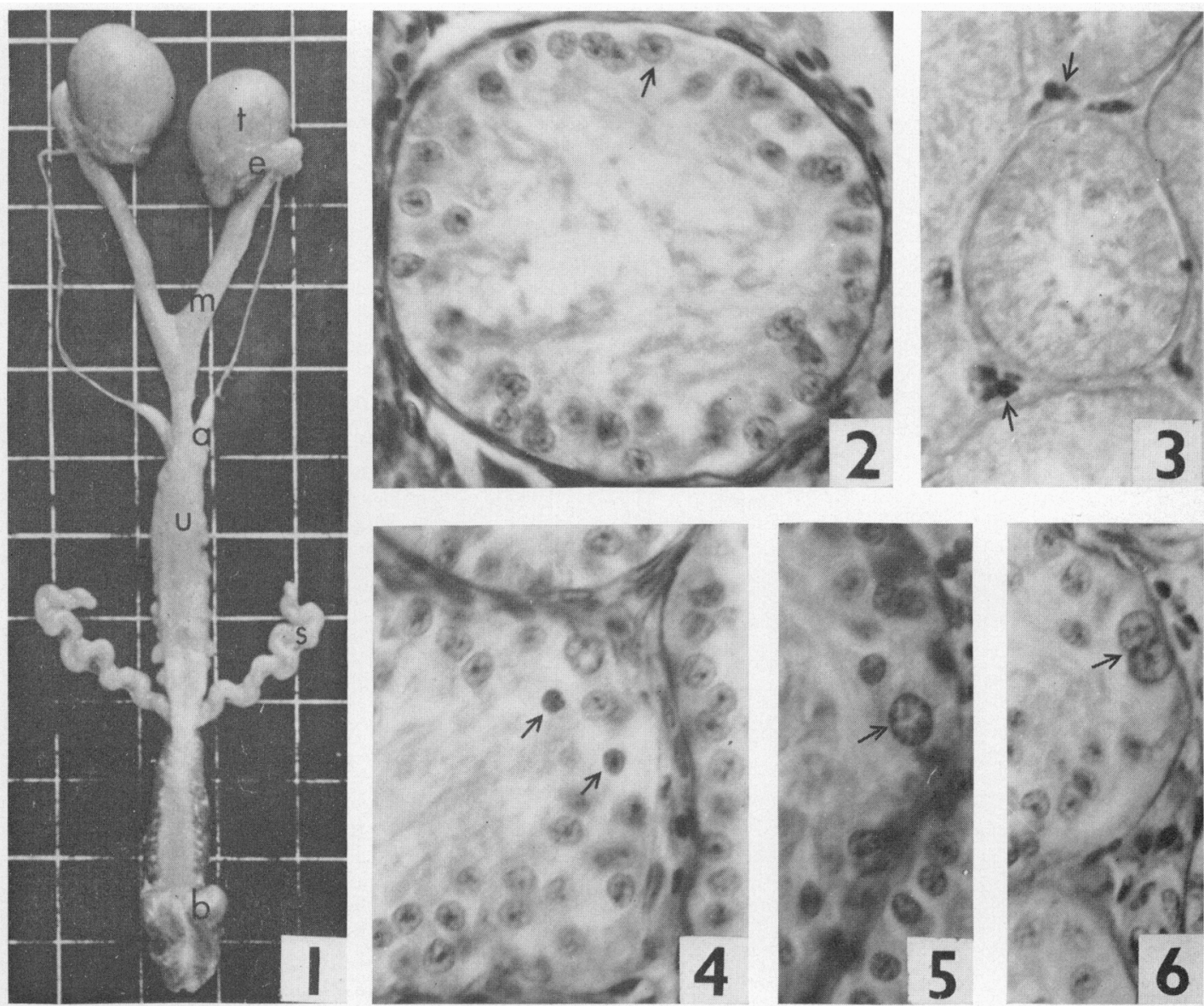

lís. 1. Reproductive tract showing testes (t), epididymides (c), Müllerian ducts (m), ampullac (a). uterus masculinus (ui, seminal resicles (s) and bulbourcthral glands ( $b$ ). (Scale in inches.)

Fig. 2. Transverse section through a testicular seminiferous tubule showing sustentacular cells but no germ cells $(\times 512)$.

Fic: 3. Transverse section through the testis showing Lcydig cells stained with Sudan black $(\times 512)$.

Frr: 4. Transverse section through the testis showing spermatogonia $(\times 512)$.

Firs. 5 and 6. Transwerse rections through the testis showing primary spermatocytes $(\times 512)$. 